\title{
Inequality in America and Spillover Effects on Mediation Practice: Disputing for the 1 Per Cent and the 99 Per Cent
}

\author{
Ellen Waldman ${ }^{*}$
}

\begin{abstract}
We are living in an era of vast inequality. Income and wealth gaps between 'the haves' and 'have-nots' have reached epidemic proportions. The top 1 per cent of earners in the United States pulled in a whopping 19.3 per cent of household income in 2012, their biggest slice of total income in more than 100 years. In 2014, the World Economic Forum listed severe income inequality as the number one global risk and Tom Piketty's unlikely best seller, Capital in the 21st Century, documented the rising ratio of wealth to income and the growth of a 'rentier class'. Even in Australia, where the mining industry continues to power economic growth, the income and wealth gap between the lowest and highest quintile of earners is stark. According to recent data, the top 20 per cent of Australians earn five times the income of the bottom 20 per cent, while holding 71 times more wealth. The question for mediation scholars and practitioners is whether this growing gap is affecting the way in which society's 'haves' and 'have-nots' access and experience mediation. At the low end of the socio-economic totem pole, government cuts in legal services - combined with mediation practitioners' obsession with neutrality - potentiate uninformed decision-making by unrepresented parties. At the high end, models of practice catering to legal professionals' preferences threaten to rob mediation of its transformative, therapeutic potential. This paper will explore these troubling developments and query whether growing social inequality should precipitate shifts in our thinking about mediation ethics and the way we educate the next generation of lawyers.
\end{abstract}

\section{INTRODUCTION}

Today, more than at any time since the Great Depression, we live in a world of haves and have-nots. ${ }^{1}$ For a period of roughly 30 years, beginning at the end of World War II and extending through the early 1970s, the United States boasted a robust middle class and relatively low levels

* I thank research assistant Andrei-Vladimir Dumitrescu for his excellent assistance and general gung-ho attitude.

1 See Emmanuel Saez and Gabriel Zucman, Exploding Wealth Inequality in the United States (20 October 2014) Vox <equitablegrowth.org/exploding-wealthinequality-united-states/ $>$ ('The share of wealth held by the top 0.1 per cent of families is now almost as high as in the late 1920s when 'The Great Gatsby' defined an era that rested on the inherited fortunes of the robber barons of the Gilded Age'). 
of income inequality. ${ }^{2}$ But, for the last four decades, income and wealth inequality have been rising precipitously. ${ }^{3}$ Currently, the top 10 per cent of American earners take in roughly 49.9 per cent of total income, a level of income concentration almost unparalleled in American history. ${ }^{4}$ The income share of the top 1 per cent increased from 20.1 per cent in 2013 to 21.2 per cent in $2014 .^{5}$ While rich and poor alike lost financial ground during the Great Recession of 2008, higher earners have regained their footing, while the average Joe (or Josephine) lag behind. From 2009-2014, the incomes of the top 1 per cent grew by 27.1 per cent, while the income of the bottom 99 per cent grew by only 4.3 per cent. Essentially, the top 1 per cent captured 58 per cent of the income gains in the five years post-2008 when the economy was stabilising. ${ }^{6}$

The growing chasm separating each rung of the earnings ladder makes for grotesquely lop-sided ratios between CEO pay and the salary of an average worker. Reports from union databases estimate the multiplicand to be roughly $331: 1,{ }^{7}$ growing from $42: 1$ in 1980 , to 107:1 in 1990, before increasing to its current dizzying levels. ${ }^{8}$

$2 \quad$ Emmanuel Saez, 'Striking it Richer: The Evolution of Top Incomes in the United States' (Winter 2008) Pathways: A Magazine on Poverty, Inequality, and Social Policy 6. See also James K Galbraith, Inequality and Instability: A Study of the World Economy Just Before the Great Crisis (Oxford University Press, 2012) 124, where Galbraith observes: 'Strange though it may now seem, for the first forty years after World War II the topic of economic inequality in America was a backwater, attracting little interest and very little research. Among economists, a broad consensus held that inequality was stable or declining, that the American middle class was dominant in both economics and politics and would remain so, and also that it was destined to absorb rich and poor alike into a single common social net.'

3 See Stephen M Caliendo, Inequality in America: Race, Poverty and Fulfilling Democracy's Promise (Westview Press, 2015), 41-52. 'In 2009, the highest quintile of earners collected 50 per cent of the total income in the United States. In contrast, the bottom three quintiles combined brought in just 26.7 per cent of the total income that year (with the second-highest quintile earning 23.3 per cent). There has been a steady increase in this trend over the past forty years, such that the top 5 per cent of earners in 1970 pulled in 16.6 percent. ... In 2011, the top 5 percent of households earned 21.5 percent of the total income. ... While the income gap is large (and growing), the wealth gap is even more dramatic ... Specifically, the top 10 percent of US households now control 56 percent of the nation's wealth (up from 49 percent in 2005).' See also Galbraith, above n 2, 292 ('[T] he massive rise of inequality in the global economy from 1980 to 2000, with a peak in most countries - including the United States - in the millennial year, is a fundamental reflection of the concentration of income and wealth among the richest of the rich, and the corresponding financial fragility affecting everyone else').

4 See Saez, above n 2, 1, noting that the top 10 per cent earned 50.6 per cent of the total income share in 2012. See also Thomas Piketty and Emmanuel Saez, 'Inequality in the Long Run' (2014) 344(6186) Science 838.

5 Saez, above $\mathrm{n} 2$.

6 Ibid.

7 See Kathryn Dill, 'CEOs Earn 331 Times As Much As Average Workers, 774 Times As Much As Minimum Wage Earners', Forbes, 15 April 2014, Forbes <www.forbes. com/sites/kathryndill/2014/04/15/report-ceos-earn-331-times-as-much-as-average-workers-774-times-as-much-as-minimum-wage-earners/\#100e8c2378ef>. See Caliendo, above n 3, 43. 
Shifting the focus from income to wealth, the numbers are even starker. Defining wealth as the sum of all assets people own, including homes, pensions and bank accounts, economists have noted a surge in wealth inequality in the United States over the past several decades. ${ }^{9}$ Comparing the growth in average or mean household wealth with the median of wealth distribution reveals wealth gains at the top accompanied by slowed growth or declines at the bottom. For example, between 1983 and 1989, the share of marketable net worth held by the top 1 per cent rose to 37 per cent in 1989. During that same period, the share of wealth held by the bottom 80 per cent fell from 19 per cent to 16 per cent. ${ }^{10}$ More recent estimates based on tax records suggest that the top 1 per cent of households own close to 42 per cent of total wealth (nearly double the wealth held by the bottom 20 per cent) and that wealth inequality continues to accelerate driven largely by spectacular increases garnered by the top 0.01 per cent. ${ }^{11}$

These disparities are not freakish anomalies limited to the United States economy. The trend toward wealth and income inequality is global in nature. Today, seven out of 10 people live in countries where inequality today is greater than it was 30 years ago. ${ }^{12}$ Moreover, in most countries around the world, inequality is increasing at ever accelerating rates. According to data compiled by Oxfam International, the wealthiest 1 per cent command more of the world's wealth than the rest of the population combined. ${ }^{13}$ And, in 2015, just 62 individuals had the same wealth as 3.6 billion people comprising the bottom 50 per cent of earners round the globe. $^{14}$

The standard tool for measuring inequality is the Gini Coefficient, which measures the absolute difference in living standard (either income or wealth) between two individuals chosen at random in the population, in relation to the average standard of living of the population as a whole. A zero Gini Coefficient would reflect perfect equality (each individual earning or consuming the exact same amount), while a Gini Coefficient of 1 would reflect perfect inequality (where all income or consumption would be garnered by one person). ${ }^{15}$ In the 1980 s the average Gini Coefficient for countries in the OECD was 0.29 ; by the late 2000 s, that average had

$9 \quad$ See Emmanuel Saez and Gabriel Zucman, 'Wealth Inequality in the United States since 1913: Evidence from Capitalized Income Tax Data' (2016) 131(2) The Quarterly Journal of Economics 519, 523.

10 See Edward N Wolf, 'Household Wealth Inequality', in David Cay Johnston (ed), Divided: The Perils of Our Growing Inequality (The New York Press, 2014) 93.

11 Saez and Zucman, above n 9, 21-22.

12 Oxfam International, Even It Up: Time to End Extreme Inequality (October 2014) $8<$ www.oxfam.org/sites/www.oxfam.org/files/file_attachments/cr-even-it-upextreme-inequality-291014-en.pdf>.

13 Ibid.

14 Ibid.

15 See François Bourguignon, The Globalization of Inequality (Princeton University Press, 2015) 18. 
risen 10 per cent to $0.316 .{ }^{16}$ The first years of the 21 st century marked rises in income inequality, not only in countries like the United States, Mexico and Israel, with pre-existing elevated levels, but in traditionally more egalitarian nations like Germany and the Scandinavian countries. ${ }^{17}$ Inequality has also been on the rise in many developing countries. China, major portions of Africa and Latin America have also witnessed spikes in the chasm separating those who have and those who want. ${ }^{18}$

We know that the rich and poor experience radically different opportunities, and that these differences exist in education, ${ }^{19}$ in healthcare,${ }^{20}$ and in the prospect of social mobility. ${ }^{21}$ The same is true when considering access to justice. When entering the adversary system, poorly resourced 'oneshotters' fare poorly as compared to more sophisticated repeat-players, ${ }^{22}$ and multiple studies indicate that the private judging industry is set up to benefit profitable businesses at the expense of individual consumers. ${ }^{23}$

16 Organisation for Economic Co-operation and Development (OECD), An Overview of Income Inequality in OECD Countries (2011) $22<$ www.oecd.org/els/ soc/49499779.pdf>.

17 Ibid.

18 Bourguignon, above $\mathrm{n}$ 15, 53-55.

19 See Sean F Reardon, 'No Rich Child Left Behind' in David Cay Johnston (ed), Divided: The Perils of Our Growing Inequality (New York Press, 2014) 123 ('... the academic gap is widening because rich students are increasingly entering kindergarten much better prepared to succeed in school than middle class students').

20 See Richard Wilkinson, 'Health and Income Inequalities Are Linked' in David Cay Johnston, Divided: The Perils of Our Growing Inequality (The New York Press, 2014) 163 ('A large number of studies have now reported empirical relationships between inequality and various health measures').

21 See Miles Corak, 'Income Inequality, Equality of Opportunity, and Intergenerational Mobility' (2013) 27(3) Journal of Economic Perspectives 79, 80. Corak discusses the 'Great Gatsby Curve', which reveals an association between inequality and earnings mobility across generations.

22 See Marc Galanter, "Why the "Haves" Come Out Ahead: Speculations on the Limits of Legal Change' (1974) 9(1) Law and Society Review 95, 98-103. Galanter argues that repeat players can maximize long-term gain in litigation by developing advance intelligence, planning for future engagement, developing trust and legitimacy with court personnel and, playing for favourable rule development.

23 See Lisa Bingham, 'Employment Arbitration: The Repeat Player effect' (1997) 1 Employee Rights and Employment Policy Journal 189, 205-207 (discussing an empirical study of 270 arbitration awards and establishing that employees 'win less frequently and recover a lower proportion of their claims ... in cases involving repeat player employers'); Alexander Colvin, 'An Empirical Study of Employment Arbitration: Case Outcomes and Processes' (2011) 8 Journal of Empirical Legal Studies 1 (finding considerable repeat player effect, especially for those claimants using the same arbitrator over time); Ryan Lamare and David B Lipsky, 'Employment Arbitration in the Securities Industry: Lessons Drawn from Recent Empirical Research' (2015) 35(1) Berkeley Journal of Employment \& Labor Law 113, 120 (finding evidence of repeat-player effect); David Horton and Andrea Chandrasekher, 'After the Revolution: An Empirical Study of Consumer Arbitration' (2015) 104 Georgetown Law Journal 57 (noting that judicial endorsement of class action waivers has created a class of 'extreme repeat players' who enjoy significant advantage when pitted against one-shot consumers in the 
What then does this rising tide of inequality portend for users' experience of mediation? Will extra-judicial disputing be an equalising platform where prince and pauper alike enjoy shared experiences of empowerment and recognition, or will mediation mirror other social institutions beset by socio-economic disparities and market segmentation? This article suggests that mediation, with its chameleon-like qualities, ${ }^{24}$ is well on its way to becoming a process whose methods and impact are profoundly shaped by the socio-economics of its users. In dissecting the role resources play in obtaining favourable legal outcomes, LoPucki and Weyrauch opine, 'One can no more predict the outcome of a case from the facts and the law than one can predict the outcome of a game of chess from the positions of the pieces and the rules of the game. In either case, one needs to know who is playing. ${ }^{25}$

In mediation, too, it matters who is playing. When assessing how mediation is working, we need to ask: Are the disputants low-wage workers or neighbours on social security whose small claims complaints have been shunted into court-connected mediation, or are they corporate representatives who have hired elite neutrals to help dispose of the cases brought against them with a minimum of cost and publicity? This article argues that we are entering an era where mediation for the 1 per cent looks very different from the mediation available to the 99 per cent. At the top end, mediation continues to morph into a settlement-conference mould, driven by attorney preference as well as the habits of retired litigators and judges who populate elite mediator ranks. At the bottom end, the population of unrepresented parties continues to grow, while the resources available

arbitral forum); Carrie Menkel-Meadow, 'Do the "Haves" Come Out Ahead in Alternative Judicial Systems? Repeat Players in Alternative Dispute Resolution' (1999) 15 Ohio State Journal on Dispute Resolution 19, 44-54.

24 Note, 'The Sultans of Swap: Defining the Duties and Liabilities of American Mediators' (1986) 99 Harvard Law Review 1876, 1977-1878 (arguing that mediators are 'institutional chameleons' who assume different roles in different institutional settings); Eric Galton, 'Mediation of Medical Malpractice Claims' (2000) 28 Capital University Law Review 321, 328 ('Despite attempts to characterize mediators - that is, facilitative, evaluative, empowerment, interests based, etc. - all successful mediators, as I have written before, are inherently "chameleon-like". "Chameleon-like" mediators attempt to identify the needs of the parties to a particular dispute and adjust both their demeanor and the process to meet these needs'); Urska Velikonja, 'Making Peace and Making Money: Economic Analysis of the Market for Mediators in Private Practice' (2009) 72 Albany Law Review 257, 278 ('Great mediators are creative and able to teach parties how to mediate during the mediation without controlling the process ... They are "chameleon-like": usually evaluative, but able to adjust their demeanor and mediation style to the party and the dispute.')

25 Lynn LoPucki and Walter O Weyrauch, 'A Theory of Legal Strategy' (2000) 49 Duke Law Journal 1405, 1472. LoPucki and Weyrauch use historical examples from the development of bankruptcy reorganisation to argue: 'Resources matter because they unleash strategy, and strategy is capable of altering legal outcomes across a wide range of possibilities. Adverse legal doctrine defeats only those who believe it can. For nonbelievers, the strategic application of resources can construct outcomes to order, within cultural limits. The more resources the party can spend, the better the outcomes the party is likely to get.' 
to state and federal courts shrink, leading to cuts in mediation program resources, training and small claims adviser offices. Mediators working with lower-income and working class litigants are typically scantily trained volunteers, with limited access to legal advisers. If these mediators do have legal training, they are nonetheless hamstrung by ethics prohibitions that limit their ability to provide meaningful information to disputants eager to learn of their legal entitlements. If mediation at the top-end is proving highly attuned to the process preferences of disputant representatives, mediation at the bottom-end has become a process tool of the courts, one increasingly tone-deaf to the informational needs of its users.

So, what is to be done? For low-income disputants, those forced by need to navigate the adversary system bereft of counsel, it has been suggested that some combination of self-help clinics, unbundled legal services, ${ }^{26}$ reinvigorated funding for state courts ${ }^{27}$ and greater involvement on the part of judicial officers and court personnel ${ }^{28}$ can help. This essay adds to this set of recommendations by urging a relaxation of the ethics rules that caution mediators from providing disputants with legal information. Although ethics codes do not outright prohibit the provision of information, ${ }^{29}$ mediators remain wary of discussing legal norms with parties for fear of compromising their impartiality. ${ }^{30}$ Although impartial-

26 See Jessica Steinberg, 'In Pursuit of Justice? Case Outcomes and the Delivery of Unbundled Legal Services' (2011) 18(3) Georgetown Journal on Poverty Law and Policy 453 (urging empirical assessment of self-help clinics).

27 Executive Summary, The Vermont Joint Commission in the Future of Legal Services, 41 WTR Vermont Br Journal 17, 18 (Winter, 2016): '[T]he courthouse should be seen as a community center for resolving legal disputes, much like a hospital is the center for medical issues. Other states have provided clinics and legal advice service centers at state courts, staffed with attorneys who can give limited legal advice, assist with forms and resources, and steer pro se litigants through the process.'

28 Rebecca Albrecht et al., Judicial Techniques for Cases Involving Self-Represented Litigants, 42 No. 1, Judges' J. 16 (Winter, 2003).

29 The Model Standards adopted by the American Bar Association, American Arbitration Association and Association for Conflict Resolution in the United States are typical in providing somewhat mixed messages. Under the Standard discussing Self-Determination, the Standards state that informed decisionmaking is a fundamental value, but also note that 'a mediator cannot personally ensure that each party has made free and informed choice.' Additionally, when discussing Quality of the Process, the Standards caution, 'A mediator may provide information that the mediator is qualified by training or experience to provide, only if the mediator can do so consistent with these Standards.' In other work, I have characterised the Model Standards as casting a yellow 'go slow' light over the mediator's role as educator. See Ellen Waldman, Mediation Ethics: Cases and Commentaries (Jossey Bass, 1st ed, 2011) 114.

30 See Lela Love, Comments on Cases 5.3 and 5.4 in Waldman, above n 29, 141 ('The preference for informed consent does not authorise the mediator to serve as the source of legal (or other) counsel that could direct a decision. Mediator impartiality is central to the mediation process'). See also Michael Moffitt, Comments on Cases 6.2 in Waldman, above $n$ 29, 169 ('... if the mediator tells [a hypothetical defendant] that he is a fool for making this decision without consulting an 
ity is an important value for mediators, so is informed decision-making, and unfortunately, the latter value is currently being sacrificed on the altar of the former. ${ }^{31}$

High income individuals and corporations pursuing mediation face a different self-determination paradox. The mediators they work with are experienced and highly compensated - eager to please their clientele. ${ }^{32}$ However elite mediators tend to view counsel or insurance claims personnel as the real client - and thus are gearing the process to meet the aims of those repeat players. As a result, joint sessions are giving way to pure-caucus models and the business representatives and individual parties who might, in an earlier time, have been encouraged to participate actively in discussions are relegated to positions of relative passivity. ${ }^{33}$ If mediation is touted as a process devoted to party self-determination, it is attorneys and payers whose autonomous process choices are achieving free expression, while clients sit off to the side.

The remedy for this undesirable trend is thought to lie in the arena of legal education. ${ }^{34}$ If attorneys emerge from law school better schooled

attorney, the mediator is at risk of impairing [defendant]'s self-determination in this case.'). See also James Stark, 'Preliminary Reflection on the Establishment of a Mediation Clinic' (1996) University of Connecticut School of Law Faculty Articles and Papers 486-487. Here Stark comments, as a supervisor of a small claims clinic, that 'the question of whether a mediator should provide ... [any] evaluation is vigorously contested', and notes the tension between the preference for informed decision-making and concerns about compromising impartiality.

31 See Amy Appelgate and Connie Beck, 'Self-Represented Parties in Mediation: Fifty Years Later It Remains the Elephant in the Room' (2013) 51 Family Court Review 87, 93-96, discussing the problem of uninformed, unrepresented parties in divorce mediation and discussing State ethics codes and court rules that warn against unauthorised practice by non-attorney mediators and conflict of interest concerns for attorney-mediators. See also Jacqueline Nolan-Haley, 'Informed Consent in Mediation: A Guiding Principle for Truly Educated Decision-making' (1999) 74 Notre Dame Law Review 775, 787, arguing that in court-connected mediation, mediators ought to be responsible for ensuring party informed consent. Compare Michael T Colatrella, Jr, 'Informed Consent in Mediation: Promoting Pro Se Parties Informed Settlement Choice' (2013) 15(3) Cardozo Journal of Conflict Resolution 705, 706, who argues that imposing a duty of informed outcome consent on the mediator would create a significant conflict with the mediator's ethical obligation of impartiality.

32 See Bryant G Garth, 'Tilting the Justice System: From ADR as Idealistic Movement to a Segmented Market in Dispute Resolution' (2001) 18(4) Georgia State University Law Review 930. There is a very special elite group of judges, retired judges, commercial courts, mediators, and arbitrators who provide tailormade justice geared specifically to large business disputes - a category that includes the new wave of large class actions. This elite has its own sets of lawyers as well, and this relatively small group dominates the agenda for federal court reform as well as the elite ADR market.

33 Cole et al, Mediation: Law, Policy and Practice (West/Thomson, 2011) [14:14]. Research has shown that lawyers play dominant roles in civil case mediation sessions, sometimes to the exclusion of participation by their clients.

34 See Jacqueline Nolan-Haley, 'Mediation: The "New Arbitration"' (2012) 17 Harvard Negotiation Law Review 61, 93, commenting that 'We need more skilled and better trained and equipped mediators to reign in the unbounded 
in the transformative possibilities that mediation provides, they may be more willing to give up some control, sit in joint sessions and let their clients talk. A more diverse mediation pool may also reshape the process in positive ways. What is clear is that, for the 1 per cent, if current trends continue, mediation will look more and more like arbitration or settlement conferencing, and its unique qualities as a dialogic process will be lost.

In sum, mediation is changing, ${ }^{35}$ and it is changing in line with the growing cleavages between rich and poor. Mediation at the economic bottom is shaped by lean institutional budgets and constricted resources, evolving in ways that generate a set of problems not adequately considered by the field's original architects. At the top end, a small set of elite mediators cater to the needs of repeat users, creating a process comfortable for attorneys and mediators, but arguably less useful to the disputants whose needs originally inspired its growth.

\section{Mediation for the 99 Per Cent}

Despite an alleged glut of lawyers, for poor and working class disputants, legal assistance is often out of reach. For every client served by legal aid provided by the government, one person is turned away due to a lack of resources. ${ }^{36}$ On average, low income households experience from one to three legal needs a year in the vital areas of housing, healthcare, domestic relations, and personal safety. Yet, only roughly one in five of those important needs are handled with the help of an attorney. ${ }^{37}$

and overly zealous advocacy displayed at mediation'; Nancy A Welsh, 'Musings on Mediation, Kleenex, and (Smudged) White Hats' (2011) 33 University of La Verne Law Review 5, 24. We could encourage lawyers to read Professor John Lande's or others' books on negotiation, mediation, and mediation representation. Even better, we could encourage lawyers to enrol in hands-on skills training in negotiation, client counselling, or mediation representation. They could learn to mirror and acknowledge their clients' emotions, make apologies, and incorporate reflective practice into their lawyering.

35 See Tom Stipanowich, 'The International Evolution of Mediation: A Call for Dialogue and Deliberation' (2015) 46 Victoria University of Wellington Law Review 1191. Stipanowich here describes the evolution of mediation in the United States, Australia, New Zealand and other common law countries as 'the Quiet Revolution' and suggests that these changes should prompt inquiry into 'what, if any, impact ... there be on the rendition of justice from the standpoint of perceived fairness or effectiveness of the process, and the result, cost and time-savings'.

36 See Legal Services Corporation, Documenting the Justice Gap in America: The Current Unmet Civil Legal Needs of Low-Income Americans (September 2009) <www.americanbar.org/content/dam/aba/migrated/marketresearch/ PublicDocuments/JusticeGaInAmerica2009.authcheckdam.pdf>.

37 See National Center for State Courts, Importance of Funding for the Legal Services Corporation From the Perspective of the Conference of Chief Justices and the Conference of State Court Administrators (30 March 2012) <www.ncsc. org/ /media/Files/PDF/Services\%20and\%20Experts/Government\%20Relations/ LSC_WHTPR.ashx>. 
The economic crisis of 2008-2011 exacerbated a decades-long trend toward increased need for legal assistance. Workers precariously perched in the lower reaches of financial stability faced job loss, persistent unemployment and, often, home foreclosure. ${ }^{38}$ The economic downturn led growing numbers of people to seek help claiming unemployment insurance benefits, food stamps, Medicare coverage, protection from abusive spouses and assistance obtaining unpaid wages. ${ }^{39}$ At the same time, traditional sources of funding for legal aid dropped precipitously. Legal assistance at the local level is provided through federal grants distributed by the Legal Services Corporation. Secondarily, additionally monies are provided by Interest on Lawyers Trust Account fund (IOLTA) - a fund that grows when interest rates and business activity are at a high water mark. From 2008-2011, IOLTA funds plummeted as interest rates hovered near zero and real estate sales ground to a halt. Meanwhile, federal appropriations to the Legal Services Corporation stagnated at numbers close to 1980s levels. ${ }^{40}$ According to recent documents, funding for legal aid remains at a near all-time low. If LSC's funding had kept pace with inflation, when compared with a mid-1990s appropriation, the agency's funding would be more than $\$ 600$ million; instead, the nation's legal aid offices limp along, today, on nearly half that allocation.

Just as the Great Recession fuelled a funding drought for legal aid, it also led to a series of disastrous budget reductions for state courts. In 2010, roughly 40 states cut their courts' funding. ${ }^{41}$ In California, during the 2011-2012 budgetary year, nearly $\$ 350$ million was sliced off the state court's operating budget; continued cuts led to a cumulative loss of $\$ 652$ million over the next four years. ${ }^{42}$ In North Carolina, the state court budget endured $\$ 80$ million in reductions from 2009 to $2013 .{ }^{43}$ In Massachusetts, between 2008 and 2014, non-judicial staffing increased by 4.9 per cent, while trial court staffing, including judges, clerical staff

38 See Michael Greenberg and Geoffrey McGovern, 'An Early Assessment of the Civil Justice System After the Financial Crisis: Something Wicked This Way Comes?' (2012) RAND Corporation (online) <www.rand.org/pubs/occasional_papers/ OP353.html>.

39 See Brennan Center for Justice, Civil Legal Services: Low-Income Clients Have Nowhere to turn Amid Economic Crisis (2010) <www.brennancenter.org/sites/ default/files/legacy/Justice/CLS/LSC-\%20New\%20Need.pdf>.

40 See American Association of Law Libraries, Legal Services Corporation Funding for Fiscal Year 2014 (May 2013) <aallnet.org/Documents/Government-Relations/ Issue-Briefs-and-Reports/2013/LSCFY14onepager.pdf> ('LSC currently funded at just 50.1 million more than in 1980').

41 Sandy Atkins, 'State Budget Cuts Threaten Public Access to Courts, National Center for State Courts' (2011) National Center for State Courts <www.ncsc.org/ Newsroom/Backgrounder/2011/Court-Budget-Cuts.aspx>.

42 Maria Dinzeo, 'Nation's Biggest Court Dealt 'Crippling Blow”, Courthouse News Service, 5 March 2012 <www.courthousenews.com/2012/03/05/44425.htm>.

43 Sharon McCloskey, 'Budget Cuts, Recession Batter North Carolina Courts, Threaten Justice' NC Policy Watch, 16 January 2013 <www.ncpolicywatch. com/2013/01/16/budget-cuts-recession-batter-nc-courts-threaten-justice/>. 
and probation personnel, decreased by over 16 per cent. ${ }^{44}$ In Florida, state court appropriations declined from $\$ 477$ million in the 2007-2008 fiscal year to $\$ 443$ million for the 2013-2014 fiscal year, and while court fees generated significant revenues, a significant percentage of those revenues were siphoned off to other branches of government. ${ }^{45}$ Georgia's court budget sustained a 15 per cent cut in $2009,{ }^{46}$ while the Massachusetts courts system's operating budget fell by over $\$ 52$ million from 2009 to $2012 .{ }^{47}$ From 2012 to 2013, seven states saw reductions in their appropriations compared to the previous year, while seven states' budget allocations plateaued at previously reduced levels. ${ }^{48}$

These budget cuts led to courthouse closures, staff layoffs and furloughs, salary caps, supply shortages, and case processing delays. Importantly, for disputants interested in mediation, they led to changes that would adversely affect the quality of the mediation experience. In Montana, the Pro Bono office and Self-Help Law Program, programs designed to help unrepresented parties navigate the Montana courts, was cut from the Judicial Branch budget. ${ }^{49}$ In Oregon, programs offering procedural assistance to self-represented litigants were reduced, replaced, in the main, by online videos and form $s .{ }^{50}$ Similarly, pro bono coordinators and administrative personnel tasked with helping unrepresented parties were the first to lose jobs when $\$ 170$ million was slashed from the New York State court system. ${ }^{51}$ After years of budget cuts and unprecedented staff reductions in some of California's poorest courts and communities, one Presiding Judge in 2012 noted, 'Our court has been operating on a

44 'Justice in the Balance: Budget Overview for the Massachusetts Judiciary' 25 March 2015, 6 <www.mass.gov/courts/docs/budget/budget-overview-massachusetts-judiciary-032515.pdf>.

45 'Court Funding and Budget' Florida Courts < www.flcourts.org/administrationfunding/court-funding-budget/>.

46 Paulo Prado and Corey Dade, 'Cases Pile Up In Georgia Courts: Budget Squeeze Forces Cuts In Spending for Judiciary, Creating Months-long Delays', Wall Street Journal (online) 8 September 2009 <www.schr.org/action/resources/cases_pile_ up_in_georgia_courts_budget_squeeze_forces_cuts_in_spending_for_judiciar>

47 Massachussetts Court System, Annual Report on the State of the Massachussetts Court System: FY2012, 22 <www.mass.gov/courts/docs/fy12-annual-report.pdf>.

48 See National Center for State Courts, above n 37, 4; see also Rebecca Kourlis and Dirk Olin, Rebuilding Justice: Civil Courts in Jeopardy and Why You Should Care (Fulcrum, 2011).

49 Charles Wood, 'Programs Providing Competent Legal Help to Montanans are Falling Prey to Hard Times' (2009) 34(6) The Montana Lawyer 5.

50 See Melody Finnemore, 'A Modern Reality', Oregon State Bar Bulletin

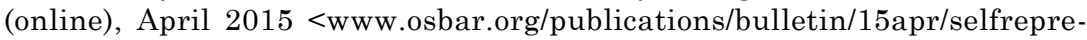
sentation.html>; see also Nicole Garcia, Examining Dissolutions Amongst Self-Represented Litigants in the Superior Court of Arizona in Maricopa County (Court Project, National Center for State Court's Institute for Court Management, 2014), discussing growth of self-represented population and courts' efforts to adjust.

51 See Vincent E Doyle III, 'Our Goal: Justice for All' (2012) 85(4) New York State Bar Association Journal 5. 
shoestring budget for many years. Now the State is taking away the shoe strings. ${ }^{52}$

This held-together-by-duct-tape court environment is perilous for low income disputants seeking redress without counsel. Mediation's original architects assumed that parties entering into mediation would know their legal rights or be accompanied by lawyers. ${ }^{53}$ In earlier days, when courts and the nation's legal aid providers were more flush, that assumption may have been reasonable. Today, it is not. The vast majority of disputants entering into lower-level court-connected mediation are ignorant of their legal entitlements. ${ }^{54}$ These litigants cannot retain private counsel and there is no place in the modern courthouse where they can obtain the information they need to make reasonably informed decisions in mediation.

The plight of the 99 per cent (or 90 per cent) is well-illustrated by the challenges facing borrowers participating in foreclosure mediation programs established in the wake of the collapse of the American housing market. At its peak, in 2010, a record 2,871,891 properties fell into foreclosure. ${ }^{55}$ From 2011-2014 over a million properties were re-possessed by banks each calendar year, ${ }^{56}$ and as recently as January 2016, 456,000 properties were in some state of foreclosure and 3.2 per cent of the nation's property stock was 'seriously delinquent' and under threat of seizure. ${ }^{57}$

In an effort to divert some portion of foreclosure disputes from the courts, many states set up mediation programs designed to bring defaulting homeowners and loan servicers together to discuss whether loan modification and home retention were possible. ${ }^{58}$ Although a

52 Superior Court of California County of San Bernardino, San Bernardino Superior Court Announces the Second Phase of Cost Reduction Measures, News Release (11 December 2012) <www.sb-court.org/Portals/0/Documents/PDF/ NewsandNotices/NewsReleaseCostReduction121112.pdf>.

53 See Christopher W Moore, The Mediation Process: Practical Strategies for Resolving Conflict (Jossey-Bass, 3rd ed, 2003) 393, discussing a mediator's ability to balance power by 'referring the party to a lawyer or other resource person' and aiding the party in 'developing financial resources so that he or she can continue to participate in negotiations'.

54 Russell Engler, 'Out of Sight and Out of Line: The Need for Regulating of Lawyers' Negotiation with Unrepresented Parties' (1997) 85 California Law Review 79 (discussing the plight of tenants in New York and Boston Housing Court and their lack of understanding of the substantive law as well as court procedures); Michele Cotton, 'A Case Study on Access to Justice and How to Improve It' (2014) Journal of Law in Society 84 (discussing a case study of a tenant in housing court whose ignorance of legal rights resulted in failure to obtain deserved award).

55 See Erin Carlyle, '2014 Foreclosure Filings Hit Lowest Level Since 2006, RealtyTrac Says', Forbes (online), 15 January 2015 <www.forbes.com/sites/ erincarlyle/2015/01/15/foreclosure-filings-drop-by-18-in-2014-hit-lowest-levelsince-2006-realtytrac-says/\#5be030133c27>.

56 Ibid

57 CoreLogic, National Foreclosure Report (January 2016) <www.corelogic.com/ research/foreclosure-report/national-foreclosure-report-january-2016.pdf $>$.

58 National Consumer Law Center, Foreclosure Mediation Programs <www.nclc. org/images/pdf/foreclosure_mortgage/mediation/summary-programs-supervised. 
small minority of these programs contemplate attorney representation throughout the process,${ }^{59}$ the vast majority do not. ${ }^{60}$ New Mexico and New Jersey's mediation program are typical in requiring borrowers to work with housing counsellors to ensure accurate completion of financial forms, but not requiring consultation or formal representation by an attorney. ${ }^{61}$ Unsurprisingly, borrowers in serious default on their home loans are not in a position to hire outside counsel. Many programs attach a list of legal aid offices or law school clinics where borrowers can seek out legal assistance. But available statistics suggest that when attorneys are merely suggested by the mediation program, homeowners go without. ${ }^{62}$ The following statistics are sobering: in Philadelphia 95 per cent of cases that completed foreclosure mediation did not register a formal appearance by an attorney; ${ }^{63}$ defendants in 74.1 per cent of cases in Connecticut's foreclosure mediation did not enjoy representation $;{ }^{64}$ homeowners in 56.6 per cent of cases completed in six judicial districts in Florida during a two-year were unrepresented; in Franklin County, Ohio, the number was 87 per cent; in Maine, the proportion was 61 per cent.

Numbers also confirm the common-sense assumption that borrower outcomes improve when attorneys are involved. The Director of the Michigan Foreclosure Prevention Project testified that in cases where attorneys have worked on foreclosure cases in their full representative capacity, borrowers have enjoyed a positive outcome in over 90 per cent of those cases. ${ }^{65}$ A comparison of six foreclosure mediation programs taking place throughout Illinois similarly highlights the correlation between

pdf>; see also Heather Scheiwe Kulp, 'Foreclosure Dispute Resolution Program Models State-By-State', Resolution Systems Institute (online), 19 September

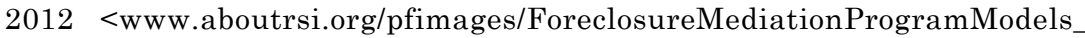
September2012.pdf $>$ (reporting on 29 states' programs).

59 See Kulp, 'Foreclosure Dispute Resolution', above n 58, noting that Cook County's Foreclosure Program assigns pro bono attorneys to each borrower.

60 Ibid, discussing Connecticut, Hawaii and Maine, which have no affiliation with legal aid and do not provide home-owners with referrals.

61 See National Consumer Law Center, above n 58, 35-39.

62 See Kulp, 'Foreclosure Dispute Resolution', above n 58, 128-132, where she notes that in the District of Columbia, which offers borrowers a list of free legal services, one mediation provider recorded only 14 per cent of borrowers represented by counsel during mediation. Similarly, In Indiana, where borrowers are told they may contact attorneys who will represent them at no charge, only 3 per cent of borrowers are represented throughout the settlement conference.

63 See Nabanita Pal, 'Facing Foreclosure Alone: The Continuing Crisis in Legal Representation', Brennan Center for Justice (New York), 4 November 2011, 4. Pal notes that this number does not capture the possibility that borrowers received legal assistance prior to their appearance at mediation.

64 Melanca Clark and Maggie Brown, 'Foreclosures: A Crisis in Legal Representation', Brennan Center for Justice (New York), 6 October 2009.

65 House Committee on Banking and Financial Services, Testimony of Lorray S.C. Brown On Behalf of the Michigan Poverty Law Program (18 April 2012) <house. michigan.gov/sessiondocs/2011-2012/testimony/Committee3-4-18-2012-3. pdf $>$. 
attorney representation and high rates of borrower home retention. ${ }^{66}$ While the authors are careful to note that correlation does not equal causation, the one foreclosure program in Illinois that assigns attorneys early in the information-gathering and negotiation preparation process also boasts the highest completion rate as well as the highest home retention rate for participating homeowners ${ }^{67}$ Although only one quarter of all participating homeowners received assistance from the Land of Lincoln attorneys, those who did retained their homes at twice the rate of those who went through the process alone. ${ }^{68}$

In developing best practices for this new brand of mediation, experts acknowledge that borrowers need support navigating the intricacies of the foreclosure process, gaining a better understanding of their financial situation, as well as determining whether any legal defences exist based on servicer misconduct. ${ }^{69}$ Debate, however, exists over whether the mediator should be free to supply such informational assistance or whether outside attorneys must be called in. ${ }^{70}$ Purists insist that the centrality of the mediator's neutral stance requires forbearance: that mediators be precluded from offering the legal and financial information that borrowers so desperately need. ${ }^{71}$ Others, prioritising borrower need over the sanctity of the third party neutral role, urge that mediators be 'un-muzzled', ${ }^{72}$ freed to help unrepresented parties better understand their rights and obligations.

This debate is not new. As early as 1999, prominent access to justice scholar Russell Engler wrote that the role of court-connected mediators

$66 \quad$ See Jennifer Shack, 'Six Programs, Six Models: An Evaluation of the Foreclosure Mediation Programs Funded by the Office Of The Illinois Attorney General', Resolution Systems Institute (online), 2015 <www.aboutrsi.org/pfimages/ SixProgramsSixModels.pdf>.

67 Ibid 160.

68 Ibid 161 (It should be noted that the 20th circuit's high retention rate may be, in part, related to the high completion rate of the program as well as the low participation levels, which may result in an informal screening of borrowers for whom retention is an unrealistic goal.) See also Russell Engler, 'Connecting Self-Representation to Civil Gideon: What Existing Data Reveal About When Counsel Is Most Needed' (2010) 37 Fordham Urban Law Journal 37, 39. Here Engler discusses a meta-analysis of studies revealing that parties represented by lawyers are between 17 per cent and 1380 per cent more likely to receive favourable outcomes in adjudication than are parties appearing pro se.

69 See Kulp, 'Foreclosure Dispute Resolution', above n 58.

70 Ibid; but see Richard Zorza, The Beginning of a Discussion of ADR and 100\% Access to Justice (20 November 2015) <accesstojustice.net/2015/11/20/ the-begining-of-a-discussion-of-adr-and-100-access-to-justice/>.

71 See Heather Scheiwe Kulp, 'Foreclosure Best Practices', Resolution Systems Institute (online), $2012<$ courtadr.org/files/ForeclosureMediationBestPractices. pdf>.

72 See Zorza, above n 70: 'To put it bluntly, there are practices in many states that muzzle the neutral from ensuring that both sides are fully informed in the process, and understand their rights and the implications of choices. So long as these stay in place, many participants in the triage design process will be pressuring to limit use of ADR to cases in which litigants are in no need for such a role being played by the neutral. This will significantly reduce the extent to which ADR models are included.' 
should change when disputants are unrepresented. Although hewing to strict notions of neutrality may make sense when each party has retained counsel, Engler argued that when disputants appear in mediation without the benefit of legal assistance, they require a different sort of treatment.

A system in which represented parties routinely prevail over unrepresented parties - without regard to the merits of the case - cannot be viewed as fair or impartial; the notion of impartiality should compel judges and mediators to assist unrepresented parties, rather than prevent them from doing so. ${ }^{73}$

When dealing with unrepresented parties, mediators should, according to Engler, assume an activist stance, ensuring that represented parties are not gaining an unfair advantage and that resulting agreements meet minimal levels of fairness. ${ }^{74}$ Engler's argument has merit, but in the almost two decades since its enunciation, the American mediation community has largely declined to expand mediator obligations toward unrepresented parties. ${ }^{75}$ Ethics codes on the state and national level speak largely with one voice in allowing mediators to provide legal information, but not legal advice. ${ }^{76} \mathrm{And}$, because the distinction is anything but clear, ${ }^{77}$ mediators dealing with unrepresented parties tend to steer clear of discussions that might place them at odds with state regulatory structures as well as unauthorised practice prohibitions.

The blurred nature of the distinction between legal information and legal advice is apparent when comparing different states' definitions. Virginia explicitly prohibits a mediator from 'applying legal principles to facts in a manner that ... in effect predicts a specific resolution of a legal issue ${ }^{78}$ while the rules for California and Florida Court mediators would

73 See Russell Engler, 'And Justice for All - Including the Unrepresented Poor: Revisiting the Roles of the Judges, Mediators and Clerks' (1999) 67(5) Fordham Law Review 1987, 1990.

74 Ibid 2032.

75 See Colatrella, Jr, above n 31, 707, arguing that while mediators should be responsible for ensuring that disputants understand the costs and benefits of entering mediation, they should not be responsible for ensuring that disputants understand the nature of the agreement they enter in mediation, as well as the legal rights waived.

76 See Supreme Court of North Carolina, Revised Standards of Professional Conduct for Mediators, Rule VI ('a mediator shall limit himself or herself to the role of mediator and shall not give legal or other professional advice during the mediation'); Florida Mediator Ethics Advisory Committee, Florida Rules for Certified and Court-Appointed Mediators, Rule 10.3709(c) ('A mediator shall not offer a personal or professional opinion as to how a court in which the case has been filed will resolve the dispute'); Interagency Alternative Dispute Resolution Working Group, A Guide for Federal Employee Mediators, Guidance Note to Standard III ('A federal employee mediator must limit his/her role to that of mediator and must never assume the role of advocate or advisor of any sort for any party's interests during the mediation process').

77 See Virginia Department of Dispute Resolution, Overview of Unauthorized Practice of Law and Mediation, <www.courts.state.va.us/courtadmin/aoc/djs/ programs/drs/mediation/resources/upl_guidelines.pdf $>$. Ibid. 
seemingly allow mediators to engage in exactly that type of speculation. ${ }^{79}$ Ironically, although California's rules do seem to leave space for mediators to educate parties about their legal entitlements and possible court outcomes, they conclude with a special admonition for a mediator working with pro se parties, 'A mediator should exercise particular caution when discussing the law with unrepresented parties and should inform such parties that they may seek independent advice from a lawyer.' ${ }^{80}$

The plight of unrepresented parties in mediation is well-illustrated by the sympathetic, yet inconclusive commentary provided by the Georgia Commission on Dispute Resolution. When discussing that state's bar on providing professional advice, the Commission noted, 'Conversations with Georgia mediators who are trained as lawyers confirmed that this concept (of avoiding professional advice) is extremely difficult for lawyer/ mediators. Lawyers, having been trained to protect others, agonise over the perception that missing information, poor representation, ignorance of a defense, may place a party in danger. ${ }^{\prime 1}$

The commission recommends, if it can be called a recommendation that 'the line between information and advice can be very difficult to find. However, failure to honour the maxim that a mediator never offers professional advice can lead to an invasion of the parties' right to selfdetermination and a real or perceived breach of neutrality.' ${ }^{22}$ Exactly how this ambiguity affects pro se parties in Georgia becomes clearer upon looking at that state's ethics advisory opinions. In Advisory Opinion 7, the Committee opined on whether mediators could assist parties with child support calculations under the provisions of Georgia's newly revised child support statute. Noting that non-attorney mediators were nervous about unauthorised practice allegations, while attorney mediators were concerned they would be accused of dual representation and professional conflict violations, the Committee clarified that mediators could

79 See Supreme Court of Florida, Florida Rules for Court-Connected Mediators, Rule 10.370 ('Consistent with standards of impartiality and preserving party self-determination ... a mediator may point out possible outcomes of the case and discuss the merits of a claim or defense'); see also Judicial Council of California, California Rules of Court, Rule 3.857 (Quality of the Mediation Process - Advisory Committee Comment Subdivision - '(d) Subject to the principles of impartiality and self-determination; and if qualified to do so; a mediator may (1) discuss a party's options, including a range of possible outcomes in an adjudicative process; (2) offer a personal evaluation of or opinion on a set of facts as presented, which should be clearly identified as a personal evaluation or opinion; or (3) communicate the mediator's opinion or view of what the law is or how it applied to the subject of the mediation, provided that the mediator does not also advise any participant about how to adhere to the law or on what position the participant should take in light of that opinion').

80 See Judicial Council of California, above n 79.

81 See Georgia Commission on Dispute Resolution, Ethical Standards for Neutrals (18 June 2013) Self-Determination/Voluntariness, <godr.org/sites/default/ files/Godr/mediator_ethics_information/APPENDIX $\% 20 \mathrm{C} \% 2 \mathrm{C} \% 20 \mathrm{CHAP} \% 20$ $1 \% 2 \mathrm{C} \% 206-18-2013 . \mathrm{pdf}>$. 
use web-based calculators and spreadsheets in helping parties calculate child support, so long as they stayed away from counselling parties as to what the inputs into statutorily based formula should be ${ }^{83}$ What is clear from the guidance provided is that mediators are expected to ask parties to categorise various forms of income and expenses so they can be plugged into existing tables, but are prohibited from explaining the legal or financial effect of such characterisations. ${ }^{84}$ This is exactly the sort of partially informed decision-making that renders mediation a dangerous place for pro se parties. Unfortunately, the dangers have not lessened over time. If anything, they have increased.

\section{Mediation for the 1 Per Cent}

Mediation at the higher ends of the socio-economic echelon is not dangerous so much as disappointing. For a number of years, many commentators have suggested that the dialogic aspect of mediation ${ }^{85}$ is in decline and that what began as a process focused on relationship-repair and, creative problem-solving has devolved into a numbers game. ${ }^{86}$ Recently, some limited empirical evidence has emerged to give credence to those claims. ${ }^{87}$

One study, jointly conducted by the Straus Institute for Dispute Resolution and the International Academy of Mediators (IAM) examined the practice preferences of mediators both in different regions or the United States as well as outside of the United States. ${ }^{88}$ When asked whether they opine regarding the legal merits of each parties' arguments, nearly 37 per cent said they usually or always do. Another 52 per cent said they offer evaluations 'sometimes' or 'about half the time'. Less than 11 per cent said that they never evaluate. ${ }^{89}$

83 Ibid.

84 Ibid. Mediators are advised to tell separated parents that amounts spent on a psychologist for their daughter must be put into one of several categories: extraordinary educational expenses, extraordinary medical expenses or special expenses of child rearing - without being told how those categorizations would affect the amount of child support due. If the counselling expense is characterized as a 'Special Expense of Child Rearing' it must equal a certain percentage of that spouse's Child Support Obligation for it to affect the amount of support the other spouse must pay. But, according to the commentary offered by the Georgia Commission on Dispute Resolution, that information cannot be provided without treading dangerously close to unauthorized practice and impermissible professional conflicts.

85 Nolan-Haley, 'Mediation', above n 34.

86 See Lela Love and Ellen Waldman, 'The Hopes and Fears of All the Years: 30 Years Behind and the Road Ahead for the Widespread Use of Mediation' (2016) 31(2) Ohio State Journal on Dispute Resolution 123.

87 See Jay Folberg, 'The Shrinking Joint Session' (2016) 22(2) Dispute Resolution Magazine 12; Tom Stipanowich, 'Insights on Mediator Practices and Perceptions' (2016) 22(2) Dispute Resolution Magazine 6.

88 See Stipanowich, 'The International Evolution of Mediation', above $\mathrm{n}$ 35, 7. The majority of study respondents are US-based, so the sample size of mediators practising outside of the US is relatively small. Ibid 10 . 
Interestingly, mediators practising in California appeared particularly inclined to opine on the legal merit of the parties' claims, with 63 per cent of California mediators reporting that they always or usually offered an opinion. Mediators practising in other parts of the United States appeared slightly less likely to provide opinions, but the percentage of United States practitioners in other regions who usually or always evaluate still surpassed 40 per cent..$^{90}$ In addition to revealing evaluative tendencies, the mediators polled in the Strauss survey also expressed a preference for conducting negotiations in a private meeting or caucus setting. ${ }^{91}$ When asked whether they begin mediation with all parties in caucus, nearly 40 per cent said they do so always or usually. ${ }^{92}$ Follow up questions revealed that nearly a quarter of all mediators always or usually keep parties in caucus during the entire mediation. ${ }^{93}$

Heavy reliance on caucus was also apparent in the survey responses of mediators from the Judicial Arbitration and Mediation Service. ${ }^{94}$ In March 2015, all 300 members of JAMS American and Canadian panels were polled regarding their use of caucus and joint sessions and changes in usage over time. The answers revealed that JAMS mediators were using the joint session less and less and that the goals for using a joint session were also in flux. ${ }^{95}$ When asked if, at the beginning of their careers, respondents had begun their mediations in joint session, slightly more than 80 per cent replied that they had. ${ }^{96}$ When asked if they currently begin in joint session, only 45 per cent said that they do. Additionally, whereas in the past, some significant portion of mediators viewed the joint session as a place where all parties could begin negotiations and explore each other's needs/interests, ${ }^{97}$ current use of the joint session is largely limited to making introductions, and explaining ground rules. The more substantive uses of the joint session for exchanging view-points and exploring interests has largely dropped out of fashion. ${ }^{98}$ The joint session is also unlikely to make a reappearance later in the process. When asked,

$90 \quad$ Ibid.

91 Ibid.

92 Ibid 7.

93 Ibid 10. Notably, mediators from different geographic regions tend toward different default patterns. Mediators in California tend to start in greater numbers in caucus and maintain a caucus structure throughout. Outside the United States, mediators are much more likely to begin in joint session and remain so throughout the mediation. American mediators practising in states other than California keep parties in a caucus less than do mediators California, but more than do non-US mediators.

94 See Folberg, above n 87.

95 Ibid.

96 Ibid 13.

97 Ibid 14.

98 Ibid 15: 'When mediators hold a joint session now, they do so for purposes similar to those from their earlier practice but with less emphasis on what might be termed the more 'substantive' purposes; clarifying the procedural status of the litigation, allowing parties to be heard by other side, discussing facts, legal theories, and beginning negotiations.' 
if you do not use an initial joint session, do you use a joint session later in the process, most said no. ${ }^{99}$

The joint session's fall from favour can be attributed to aversion on the part of both mediators and attorneys. Classically trained mediators who have been in the field a long time likely are well-familiar and comfortable with the unique challenges of directing a conversation between hostile clients and attorneys. But, career litigators and retired judges recently recruited to the mediation field are less serene in that setting. This new cohort of mediators may believe that because they are adept at analysing legal positions, engaging in decision-tree analysis and poking holes in an attorney's confidently presented case, they are well-positioned to succeed in mediation, despite not knowing how to steer an emotionally charged conversation safely into port.

The second factor leading to a decline in the use of the joint session is resistance from participating attorneys. One JAMS mediator, when questioned about declining to use a joint session, commented, 'I offer services in a crowded mediation marketplace. I heed the market's wishes on joint sessions. '100 Mediators from the Strauss survey who had abandoned the joint session also indicated that they were swayed by attorney attitudes. California mediators seem particularly responsive to attorney suasion, with mediators commenting, 'In California, counsel seem to have taken over the mediation process ... [O]n occasion, I have been specifically instructed that counsel and the parties do not even need to see each other.' ${ }^{101}$ Another mediator noted that 'at least 90 per cent of the lawyers involved in the mediations I handle do not want to start with a joint session'. ${ }^{102}$ Many attorneys are inadequately educated about the underlying goals of mediation and are nervous about the prospect of their client talking directly with opposing counsel.

Eric Galton, an early pioneer of the process and co-editor of the popular text Stories Mediators Tell ${ }^{103}$ suggested that attorneys, as gatekeepers determining whether mediators get hired or not, are exerting a disproportionate influence on the form mediation is taking in big-money court connected mediation. In his clever but ultimately disheartening article, 'The Mediation Witches', ${ }^{104}$ Galton notes that:

$[L]$ awyer advocates are the gatekeepers on mediator selection. Many mediators have worked dozens of cases or more for particular law firms or lawyers ... The Gatekeeper never has been trained in mediation ... and is typically terrible in negotiation ... But, the Gatekeeper knows what he/ she likes and is entirely willing to dictate process ... The Gatekeeper can

99 Ibid

100 Ibid 16.

101 See Stipanowich, 'The International Evolution of Mediation', above n 35, 8.

102 Ibid.

103 Lela P Love and Eric R Galton, Stories Mediators Tell (American Bar Association, 2012).

104 See Eric Galton, 'The Mediation Witches' (2015) 16(3) Cardozo Journal of Conflict Resolution 825. 
magically transform a [court-connected mediator] into the 'Go-to Mediator', or, more darkly, the 'Do-Not-Use Mediator'. ${ }^{105}$

As Galton notes, attorney-gatekeepers do not like joint sessions because they are 'either too touchy-feely or too ill tempered ... The Gatekeeper enjoys absolute control and does not favour a process that empowers party participation'. ${ }^{106}$ Galton also notes that the new breed of mediator, whom he factiously terms the Hobbyists, "have no connection, interest or passion in the ... mediation process itself'. They have little use for the messiness of the joint session, believe that disputes are all about money and if all else fails, making a mediator's proposal (picking the number) was a brilliant way to settle cases'. ${ }^{107}$

What are the implications of these changes for the 1 per cent in mediation? The situation for the well-resourced is certainly not as dire as it is for the less-resourced. But, if well-heeled clients end up being represented by Gate-keepers with an aversion to client participation and Hobbyists with no commitment to the traditional goals and structure of mediation, they are likely to end up in a caucus-only settlement conference as opposed to a real dialogic process. Their Hobbyist mediator is likely to spend her time poking holes in the client's legal position, suggesting what will happen in front of a judge, offering a bracketed range for negotiations and presenting a mediation proposal. That is a far cry from what mediation was originally intended to be - a radical alternative to adversarial processes where parties had an opportunity to take control of their dispute and forge resolutions tailored to their particular needs and interests. Mediation also was seen as a way for parties to preserve and perhaps rebuild relationships and to gain confidence in their own capacity to manage conflict successfully. None of this can happen in a mediator-centric process where parties aren't even allowed in the same room together.

\section{Conclusion}

In 1926, F Scott Fitzgerald wrote that the rich are 'different from you and me'. ${ }^{108}$ The observation still holds. Both on subjective ${ }^{109}$ and objective measures, ${ }^{110}$ the upper class experience life differently than do middle class or lower class earners. This divergence continues when rich and poor enter into mediation. The poor will likely participate in an understaffed,

105 Ibid 826-827 (emphasis removed).

106 Ibid.

107 Ibid 828.

108 F Scott Fitzgerald and Matthew J Bronccoli (eds), The Short Stories of F Scott Fitzgerald, The Rich Boy (Scribner, 1989) 335.

109 Kim Parker, Yes, The Rich Are Different (12 August 2012) Pew Research Center $<$ www.pewsocialtrends.org/2012/08/27/yes-the-rich-are-different/> (members of upper class report higher levels of satisfaction with career, family life and health than do members of middle or lower classes).

110 Melissa Kearney, Income Inequality in the United States (16 January 2014) Brookings <www.brookings.edu/research/ testimony/2014/01/16-income-inequality-in-the-united-states-kearney>. 
poorly funded public program with volunteer mediators who may, or may not, have received adequate training. Legal aid programs designed to educate pro se parties about their legal rights prior to engaging in mediation have been desperately hobbled or dismantled entirely. And, because existing ethical rules prohibit mediators from providing advice (leading many mediators in an excess of caution to avoid providing both advice and information), unrepresented parties are left to make decisions in an informational vacuum. This often leads to decisions that are not in the parties' long-term best interests.

The 1 per cent are not at risk of making poor decisions in mediations. They tend to be amply 'lawyered up'. The problem for the 1 per cent is that the transformative potential of the process they are consigned to has been entirely lost. Mediation, in the cases where wealthy clients are involved, (and where mediators have the potential to make big money) has increasingly turned into a straight-forward numbers game where lawyers exchange 'bottom lines' until the mediator's relentless pressure leads them to meet in the middle. This is not a process whose central quality, as Lon Fuller, once imagined, is 'its capacity to reorient the parties toward each other, not by imposing rules on them, but by helping them to achieve a new and shared perception of their relationship'. ${ }^{111}$

Increasing income and wealth inequality is said to be bad for society as a whole. An unequal society is an unhealthy society, even if some at the top may be living very well. ${ }^{112}$ Developments in mediation, both for the 1 per cent and 99 per cent are, similarly, bad for the field as a whole, even if some parties benefit from mediators' refusals to discuss legal norms or meet in joint session. These undesirable trends, however, can be reversed. Economists, sociologists and others who study the global trend toward inequality contend that there are some obvious policy fixes: changes in tax policy, ${ }^{113}$ government subsidies in the area of health and early childhood education ${ }^{114}$ for example. Mediation theorists have also proposed a number of fixes (some quick, others less so) to remediate some of the problems lower income - as well as higher income parties face in the process. Relaxing the ethical prohibitions against the provision of tailored legal information to unrepresented parties; educating young lawyers and would-be mediators about the non-monetary aspects of dispute resolution - these are eminently achievable goals, if only we have the political will to implement them.

111 Lon Fuller, 'Mediation: Its Forms and Functions' (1971) 44 Southern California Law Review 305, 325.

112 Richard Wilkinson and Kate Pickett, The Spirit Level: Why Greater Equality Makes Societies Stronger (Bloomsbury Press, 2009).

113 Thomas Picketty, Capital in the Twenty First Century (Harvard College, 2014).

114 James Heckman, 'The Economics of Inequality: The Value of Early Childhood Education' (2011) 35(1) American Education 31. 